http://kitaibelia.unideb.hu/

ISSN 2064-4507 (Online) • ISSN 1219-9672 (Print)

(C) Department of Botany, University of Debrecen, Hungary

25(1): 3-8.; 2020

DOI: $10.17542 /$ kit.25.3

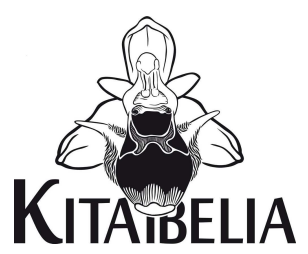

\title{
A merevszőrü boglárka (Ranunculus strigulosus) új adatai Kelet-Magyarországról
}

\author{
DEMETER László \\ Hortobágyi Nemzeti Park Igazgatóság, H-4024 Debrecen, Sumen u. 2.; demeterlaszlo@hnp.hu \\ New occurrences of Ranunculus strigulosus in East Hungary
}

\begin{abstract}
The exact distribution of Ranunculus strigulosus Schur is poorly known in Hungary. Current occurrence data of the species mainly from Békés county and only one archive data from the Nyírség region, from the 1920s were known. This study presents eleven newly discovered occurrences in East Hungary. Populations were found in wet meadows, forest glades and poplar plantations. Nine of these populations are located at the southeastern edge of the Nyírség region and most of them are quite small. Three larger population were found in Nyírábrány, Álmosd and the Tócó Valley between Debrecen and Hajdúböszörmény. One of the newly discovered populations provides a new contribution to the flora of Bátorliget Marsh and Fen-wood NCA. Some morphological characters (hairs on the stem and the leaves, shape of the leaves developed before and after the mowing) are also discussed.
\end{abstract}

Keywords: distribution, East Hungary, morphology, Nyírség region, Ranunculaceae

Összefoglaló - A merevszőrű boglárka (Ranunculus strigulosus Schur) elterjedése kevéssé ismert hazánkban. A közlemény tizenegy új lelőhelyet ír le Kelet-Magyarországról. Közülük kilenc állomány a Nyírség délkeleti szegélyén található, és többnyire igen kis egyedszámú. Három nagyobb populáció került elő Nyírábrány és Álmosd határában, valamint a Debrecen és Hajdúböszörmény közötti Tócóvölgyben. A faj kimutatása Bátorliget flórájához is új adalék.

Kulcsszavak: elterjedés, Kelet-Magyarország, morfológia, Nyírség, Ranunculaceae

\section{Bevezetés}

A merevszőrủ boglárka (Ranunculus strigulosus Schur) (syn.: R. acris L. subsp. strigulosus (Schur) Hylander, R. stevenii auct.) hazánkban ritka faj. Magyarországon a védett növények listájára került 2001-ben. Kelet- és Közép-Európában élő faj. Előfordul Romániában, Ausztriában, Szlovákiában, Ukrajnában, Szlovéniában, Horvátországban, Lengyelországban, Németországban, Grúziában és Örményországban (TuTin 1964, JALAS \& SUOMINEN 1989, [1]).

JAKAB (2012) szerint a pontos magyarországi elterjedését csak hiányosan ismerjük, mivel könnyủ összetéveszteni a réti boglárkával (Ranunculus acris L.). BORBÁs (1880) Iráz pusztán, a Sebes-Körösnél említi. Soó (1968) szinopszisa Irázt, Biharugrát, Nyírbátort, Budapestet, Kisszékelyt, valamint kérdőjelesen Kalocsát és a Bükköt sorolja fel ismert előfordulásként.

Felbukkan a faj BAUER \& BARNA (1999) Dorog és Esztergom környékéről készült fajlistájában is, pontosabb helymegjelölés nélkül. KeRTÉSz (2000) Biharugrán és Zsadányban jelzi, később (KERTÉsz 2005) beszámol róla Szabadkígyóson, és megjegyzi, hogy „Kevés adata van a Dél-Tiszántúlon, és az mind Biharugra, Komádi, Újiráz térségében”. JAKAB (2005) szintén jelzi 
Biharugra környékéről. Később megállapítja (JАКАВ 2012), hogy jelenleg biztos adatai csak a Tiszántúl déli részéről ismertek, és ezt tükrözi Magyarország edényes növényfajainak elterjedési atlaszában (BARTHA et al. 2015) a fajról készült térkép is. Ennek online adatbázisában [2] szerepel még Jakab Gusztáv és Kertész Éva flóratérképezései adata Körösnagyharsány, illetve Sarkad határából.

A Nyírségben, a Hajdúhát peremén, valamint az Érmelléki löszös háton az utóbbi években több előfordulása vált ismertté. Ezek közreadásával szeretnék hozzájárulni hazai elterjedésének pontosabb megismeréséhez.

\section{Anyag és módszer}

A faj keresésére célzott erőfeszítések nem történtek. A közölt lelőhelyek a területek más célú bejárásai során kerültek elő 2010-2019 között. Terepi észlelését nagyban segítették a romániai élőhelyeken, fóként Gyimesben, a Csíki-medencében és a Bihar-hegységben szerzett tapasztalataim. Minden állományban legalább egy tő gyöktörzsének ellenőrzésére is sor került, ami a növény kihúzása vagy kiásása nélkül is könnyen elvégezhető a néhány centiméteres talajréteg elkotrásával. A GPS-szel rögzített részletes adatok a Hortobágyi Nemzeti Park Igazgatóság nyilvántartásába kerültek.

A lelőhelyek településhatáron belüli megnevezéséhez elsősorban a Magyarország Földrajzinév-tára térképét, valamint az 1:10 000 méretarányú topográfiai térkép helyneveit használtam, és legtöbb esetben a terület pontosítását szolgáló megjegyzéseket is feltüntettem. Zárójelben adtam meg a megtalálás dátumát, és szögletes zárójelben az előfordulási helyet lefedő KEF-kvadrát kódját.

Átnéztem a Magyar Természettudományi Múzeum Növénytárának Carpato-Pannonicum gyüjteményében őrzött, - gyakran eltérő nevekkel feliratozott, de ehhez a taxonhoz tartozónak vélt - példányok digitális fotóit. A Debreceni Egyetem Herbáriumáról (DE - TAKÁCS et al. 2014, TAKÁCS et al. 2015), az ELTE Füvészkert Herbáriumáról (BPU - NóTÁRI et al. 2017), valamint az Eszterházy Károly Főiskola Edényes Növénygyűjteményéről (EGR - E. VojtKó et al. 2014) közzétett elektronikus adatbázisokban nem találtam a fajra vonatkozó adatot.

A növényfajok nevei KIRÁLY (2009) munkáját követik. Az irodalmi és herbáriumi adatok említésénél természetesen ettől eltérő neveket is idézek a forrásban szereplő eredeti írásmóddal, idézőjelbe téve.

\section{Eredmények}

Álmosd

Csuszkajó: A szórványos állományt Szél László (HNPI) találta a Bagaméri-ér menti mocsárréti kaszálón, a település közelében. Eddig mintegy 300 méter hosszú szakaszon került elő szórványosan, de ezen belül egy 0,2 ha kiterjedésű részen elég sűrü az állomány. (2019. 05. 15.) [KEF 8597.4]

\section{Bagamér}

Nagy-erdő: A Konyári-Kálló völgyének gyepjével összefüggő kelet-nyugati irányú, keréknyomokkal szabdalt erdei nyiladékon mintegy 200 töves állomány. (2018. 08. 03.) [KEF 8597.2] 


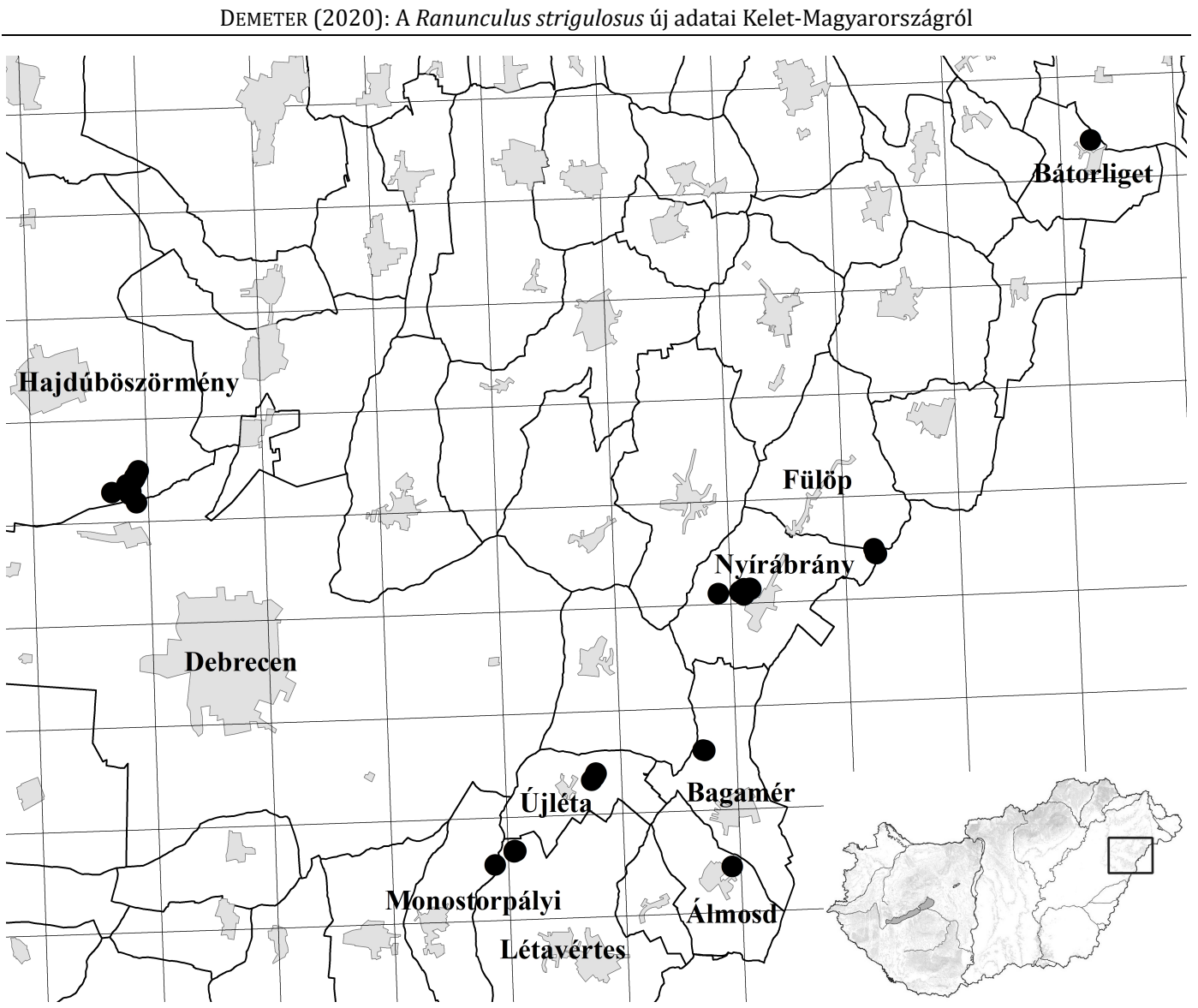

1. ábra A merevszőrű boglárka (Ranunculus strigulosus Schur) észlelt előfordulási helyei a középeurópai flóratérképezés hálórendszerének (KEF) kvadrátjaival

Fig. 1 Occurrences of Ranunculus strigulosus Schur with the quadrates of the Central European flora mapping system (CEU)

Bátorliget

Ősláp: A pallóúttól beljebb egy kisebb, nem sokkal korábban cserjétlenített tisztáson néhány virágzó példányt észleltem. (2013. 06. 27.) [KEF 8299.2]

Hajdúböszörmény és Debrecen

Tócó-völgy: Józsától északra és a hajdúböszörményi rész mindkét ágának mocsárréti kaszálóin helyenként tömeges. (2017. 06. 19-20.) [KEF 8395.3]

\section{Létavértes}

Rózner-tag: A Létai-ér két partján, a Tábor-hegytől délre eső szakaszon kisebb foltokban fordul elő. (2015. 05. 28.) [KEF 8597.3]

Fülöp

Malomkert (Zöld Marci-legelő): A faj kisebb foltja található a Penészleki I.-csatorna nyugati partján levő apró, részben kékperjés kaszálón, az államhatár közelében. A növények réti boglárkától való eltérő morfológiájára itt Józsa Árpád Csaba hívta fel a figyelmemet. (2010. 05. 04.) [KEF 8498.2]

Monostorpályi

Pályi-liget: A Málé-hegytől északra, a Létai-ér hídjánál kisebb állomány. (2015.06.04.) [KEF 8596.4] 
Nyírábrány

Hanelek: A növény a Penészleki I.-csatorna keleti partján egy hajdani láprétre telepített nyáras ültetvényben, közvetlenül az államhatár mellett szintén megtalálható Trollius europaeus L. és Angelica palustris (Besser) Hoffm. társaságában. (2010. 05. 04.) [KEF 8498.2] Káposztás-lapos: Először mindössze 10 tövet találtam a déli kaszálón levő sekély árok mentén. 2019-ben kiderült, hogy szórványos a kaszáló szegélyén, ahol szintén a réti angyalgyökérrel együtt fordul elő. (2017.06.12.) [KEF 8497.2]

Keszler-tag és Kis-Mogyorós (Árva-rész): A nyíracsádi műút két oldalán, a Konyári-Kálló menti mocsárréti kaszálókon nagy foltokban tömeges. A Keszler-tagban rekettyés füzláp szegélyén él, valamint a Konyári-Kálló partján. (2017.10. 17-18.) [KEF 8498.1]

Újléta

Steiertag (Kapott-tag): Szél Lászlóval három kisebb foltban találtuk, mocsárréten. (2011. 05. 26.) [KEF 8597.1]

Az érintett KEF-kvadrátok kódjainak összesített listája: 8299.2, 8395.3, 8497.2, 8498.1, 8498.2, 8596.4, 8597.1, 8597.2, 8597.3, 8597.4

\section{Megjegyzések a faj elterjedéséhez és morfológiájához}

A faj 11 újabb termőhelyét sikerült kimutatni, melyek 10 flóratérképezési (KEF) kvadrát területére esnek. Közülük kilenc állomány a Dél-Nyírségben van. A Konyári-Kálló menti nyírábrányi termőhelyek kivételével meglehetősen kis létszámúak, és Bátorliget kivételével viszonylag kevesek által, vagy korábban egyáltalán nem kutatott helyszíneken élnek. Mivel Bátorligetről sem említik (STANDOvár et al. 1991), úgy tűnik, hogy az Ősláp flórájára nézve is új fajnak számít. A Bagaméri-ér mentén található álmosdi állomány már az Érmelléki löszös hát területére esik. Jelenléte a jelzett helyeken talán nem annyira meglepő, hiszen a Nyírséggel szomszédos Érmellék romániai részén jól ismert növényfaj (KARÁCSONYI 1995, LESKU 2013, SzATMARI 2017). Beszámolnak róla a Bátorligethez közeli Mezőfény, Csanálos, Szaniszló, Ligettanya határából (KARÁCSONYI 1995), a hajdani Ecsedi-lápnak a romániai Börvely határába átnyúló részéről (DRAGULESCU 2005) és egyéb Nagykároly környéki településekről (SĂVULESCU 1953). Másrészt említik Ukrajnában a Felső-Tisza mentén is (HAMAR \& SÁRKÁNYKIss1999). Úgy vélem ezek alapján, hogy joggal számíthatunk további észlelésére a Nyírség, a hajdani Ecsei-láp, vagy akár a Felső-Tisza vidékén.

A Tócó-völgy állománya már jóval távolabb található ettől a határvidéktől a Hajdúhát keleti peremén, bár közvetlenül csatlakozik a Nyírséghez. Figyelemre méltónak tartom az állomány tömegességét a völgy északi részének kaszálóin, ahol jelentős kiterjedésben csaknem helyettesíti a réti boglárkát (Ranunculus acris L.), és együtt él az Alföld belső tájaira szintén nem jellemző mezei gólyaorral (Geranium pratense L.). Jelenléte talán nem mellékes adalékul szolgálhat a terület flóratörténetének jobb megismeréséhez is.

Részletes morfológiai elemzést nem végeztem a növényeken, de néhány tulajdonság megemlítését mégis fontosnak tartom, melyek a terepi azonosítást is segíthetik. Ilyen például a virágos szár alsó részén és a tőlevelek nyelének alsó részén látható mereven elálló szőrzet. Ez minden újonnan ismertté vált állományban jellemző volt, hasonlóan az általam ismert romániai növényekhez, megfigyelhető az MTM Növénytárában található erdélyi és partiumi (többnyire „R. Steveni” névvel ellátott vagy revideált) példányokon, továbbá egyezik CoLEs (1971) ilyen irányú vizsgálati eredményével, és Soó (1968) is leírja. Úgy vélem, ez a jellemző nincs teljes összhangban az Új magyar füvészkönyv $R$. acris-hoz és $R$. strigulosus-hoz irányító kulcs-részletével, miszerint: „A szár kopasz, v. szórtan rövid, rásimuló szőrü” (KIRÁLY 2009). A témához további adalék, hogy Jakab ex litt. közlése szerint a biharugrai állomá- 
nyokra nem jellemző a szőrzet általam leírt formája, így talán érdemes lenne a Dél-Alföld állományait alaposabban megvizsgálni ebből a szempontból.

A kaszáláson még át nem esett első hajtások levelein szintén egységesen megfigyelhető volt a fehéres, viszonylag hosszú, elálló szőrzet. A kaszálás után képződött leveleken ez néha ritkásabb és kevésbé feltűnő. A „tavaszi” hajtások tőleveleire szintén általánosan jellemzőek voltak a nagyrészt egyenes, vagy csak kevéssé ívelt szélű szeletekre tagolt levelek, kevés, nagy foggal. Hasonló levélalak persze a réti boglárkánál is előfordul, de leginkább az „őzi”, kaszálás után képződött levelekre jellemző. A Ranunculus strigulosus „őzi” levelei - akárcsak a $R$. acris esetén - általában a „tavasziaktól” lényegesen eltérő alakúak. Szeletei szélesek, gyakran át is fedik egymást, fogaik pedig rövidek. Így gyakran kör kerületűek. A levélalak mindamellett igen változatos lehet. A levelek közepén esetenként szabálytalan sötét folt is előfordul. A fenti tulajdonságokkal jól egyezik a Boros Ádám által 1926-ban és 1927-ben egy nyírbátori vasút menti réten gyűjtött herbáriumi példányok morfológiája, melyek a Magyar Természettudományi Múzeum Növénytárában találhatók. Ez a szeptemberben gyújtött, nem virágos példányaira is igaz, melyek a kaszálás után képződött levelek alakját mutatják.

A Nyírségen kívüli herbáriumi anyaggal kapcsolatban megemlítem még, hogy a Magyar Természettudományi Múzeum Növénytárában 423802 és 423803 számmal Schiller Zsigmond 1919-es gyüjtéséből két lap is szerepel „Ranunculus steveni” felirattal, melyek „Budapest I. Lisznyai u." gyüjtőhelyről származnak. Ezek alakja igen hasonlatos a Ranunculus acris subsp. friesianus (Jord.) Syme néven ismert nyugat-európai növények interneten megtekinthető herbáriumi példányaihoz [3]. Ráadásul CoLES (1971) szerint a Ranunculus acris csoporton belül ez az egyetlen taxon, mely rendelkezik vízszintes gyöktörzzsel. VojтKó (2001) a Bükkből jelez egy herbáriumi példányt Ómassa, Jávorkút helyszínről, Hulják János 1916-os gyűjtéséből. A példány szintén az MTM Növénytárában található, és számomra ennek levele sem tűnik tipikus „strigulosus” formájúnak. A lap „Ranunculus friseanus Jord.” eredeti felirattal van ellátva. Soó (1968) egyébiránt kétségesnek tartja a „R. frieseanus" alak és a $R$. strigulosus azonosságát, s ha a bükki lelőhelyet e példány alapján közli, talán ezért jelzi kérdőjellel. Úgy vélem, ezek a példányok még megérdemelnének egy részletes vizsgálatot.

\section{Köszönetnyilvánítás}

Köszönöm Szél Lászlónak, hogy hozzájárult álmosdi adatának közléséhez. Köszönöm Lesku Balázs hasznos tanácsait és az irodalmazásban nyújtott segítségét. Köszönöm Takács Attilának segítő javaslatait, és hogy a faj herbáriumi példányait a Magyar Természettudományi Múzeum Növénytárában számomra lefotózta. Köszönöm Jakab Gusztáv és Tóth Zoltán lektori munkáját.

\section{Irodalom}

Bartha D., Király G., Schmidt D., Tiborcz V., Barina Z., Csiky J., JaKab G., Lesku B., SchmotZer A., VidéKi R., Vојтко́ A. \& ZólYoмi Sz. (szerk.) (2015): Magyarország edényes növényfajainak elterjedési atlasza. Nyugat-magyarországi Egyetem Kiadó, Sopron, p. 214.

BAUER N. \& BARNA J. (1999): Dorog és Esztergom környékének növényvilága. - Bakonyi Természettudományi Múzeum, Zirc, p. 52.

BorbÁs V. (1880): Iráz puszta növényzete. - Magyar Orvosok és Természetvizsgálók munkálatai 20: 1-9.

Coles S. M. (1971): The Ranunculus acris L. complex in Europe. - Watsonia 8: 237-261.

Dragulescu C. (2005): Contribution to knowledge of phytodiversity of the swamp Ecedea. - Contribuţii Botanice 40: 43-53.

E. VojtKó A., TAKÁcs A., Molnár V. A. \& VojtKó A. (2014): Herbarium database of the vascular collection of Eszterházy Károly College (EGR). - Kitaibelia 19(2): 339-348. 
HAMAR J. \& SÁRKÁNY-KISS A. (szerk.) (1999): The Upper Tisa Valley - Preparatory proposal for Ramsar site designation and an ecological background - Hungarian, Romanian, Slovakian and Ukrainian cooperation - Ukrainian section I. - TISCIA monograph series, p. 38.

JАКАВ G. (2005): Adatok a Dél-Tiszántúl flórájának ismeretéhez II. - Flora Pannonica 3: 91-119.

JАКАB G. (2012): Steven-boglárka. In: JAKAB G. (szerk.), A Körös-Maros Nemzeti Park természeti értékei I. A Körös-Maros Nemzeti Park növényvilága. - Körös-Maros Nemzeti Park Igazgatóság, Szarvas, pp. 88-89.

LESKU B. (2013): Az Érmellék edényes flórája. II. rész. - Hungary-Romania Cross-Border Co-operation Programme 2007-2013. Kézirat.

Jalas J. \& Suominen J. (szerk.) (1989): Atlas Florae Europae VIII. Nymphaeaceae to Ranunculaceae. - The Committee for Mapping the Flora of Europe and Societas Biologica Fennica Vanamo, Helsinki, p. 128.

KARÁCSONYI K. (1995): Flora şi vegetaţia judeţului Satu Mare. - Editura Muzeului Sătmărean, Satu Mare, p. 42.

KerTÉsz É. (2000): Adatok a Dél-Tiszántúl flórájához. - A Békés Megyei Múzeumok Közleményei 21: 5-48.

KERTÉSz É. (2005): A Szabadkígyósi Kígyósi-puszta védett terület flórája - Natura Bekesiensis 7: 5-22.

KIRÁLY G. (szerk.) (2009): Új magyar füvészkönyv. Magyarország hajtásos növényei. Határozókulcsok. Aggteleki Nemzeti Park Igazgatóság, Jósvafő.

NótÁRI K., NAGY T., LÖKI V., LJUBKA T., MolNÁR V. A. \& TAKÁCS A. (2017): Az ELTE Füvészkert herbáriuma (BPU). - Kitaibelia 22(1): 55-59.

SĂvUlescu T. (szerk.) (1953): Flora Reipublicii Populare Române 2. - Editura Academiei Reipublicii Populare Române, pp. 615-616.

Soó R. (1968): A magyar flóra és vegetáció rendszertani és növényföldrajzi kézikönyve III. - Akadémiai Kiadó, Budapest, p. 72.

StAndovár T., Tóth Z. \& Simon T. (1991): Vegetation of the Bátorliget Mire Reserve. In: MAHunKa S. (szerk.), The Bátorliget Nature Reserves - after forty years. Vol. 1. - Hungarian Natural History Museum, Budapest, pp. 57-118.

SZATMARI P.-M. (2017): The last wetlands in the Ier Valley Natura 2000 protected area - case study: the habitats around Pir Village, Satu Mare County, Romania. - Contribuţii Botanice 52: 69-83.

Takács A., Nagy T., FeKete R., Lovas-Kiss Á., LjubKa T., LöKi V., LisZTes-Szabó Zs. \& Molnár V. A. (2014): A Debreceni Egyetem Herbáriumának Adatbázisa I.: A „Soó Rezső Herbárium”. - Kitaibelia 19(1): 142-155.

TAKÁcs A., Süveges K., LjubKa T., LöKi V., Lisztes-Szabó Zs. \& Molnár V. A. (2015): A Debreceni Egyetem Herbáriuma (DE) II.: A „Siroki Zoltán Herbárium”. - Kitaibelia 20(1): 15-22.

Tutin T. G. (1964): Ranunculus L. - In: Tutin T. G., Heywood V. H., Burges N.A., Valentine D. H., Walters S. M. \& WeBв D. A. (szerk.), Flora Europaea. Vol. 1. - Cambridge University Press, Cambridge, p. 227.

Vојтко́ A. (szerk.) (2001): A Bükk hegység flórája. - Sorbus 2001 Kiadó, Eger, p. 85.

\section{Világháló oldalak}

[1] HörandL E. \& RAAB-STRAube E. (2015): Ranunculeae. - In: Euro+Med Plantbase - the information resource for Euro-Mediterranean plant diversity.

http://ww2.bgbm.org/EuroPlusMed/PTaxonDetailOccurrence. asp? NameId=96549\&PTRefFk=750 0000 (Hozzáférés dátuma: 2019. 08. 31.)

[2] OBM - Hungarian Flora Atlas - http://floraatlasz.uni-sopron.hu/index.php?map (Hozzáférés dátuma: 2019.11. 15.)

[3] Ranunculus acris subsp. friesianus (Jordan) Syme - Global Biodiversity Information Facility https://www.gbif.org/species/8007875 (Hozzáférés dátuma: 2019.11. 03.)

Beérkezett / received: 2019. 11. 17. • Elfogadva / accepted: 2020.01. 15. 
DEMETER László (2020):

A merevszőrű boglárka (Ranunculus strigulosus) új adatai Kelet-Magyarországról / New occurrences of Ranunculus strigulosus in East Hungary

Kitaibelia 25(1): 3-8.

DOI: 10.17542/kit.25.3

\section{Elektronikus melléklet / Electronic appendix}

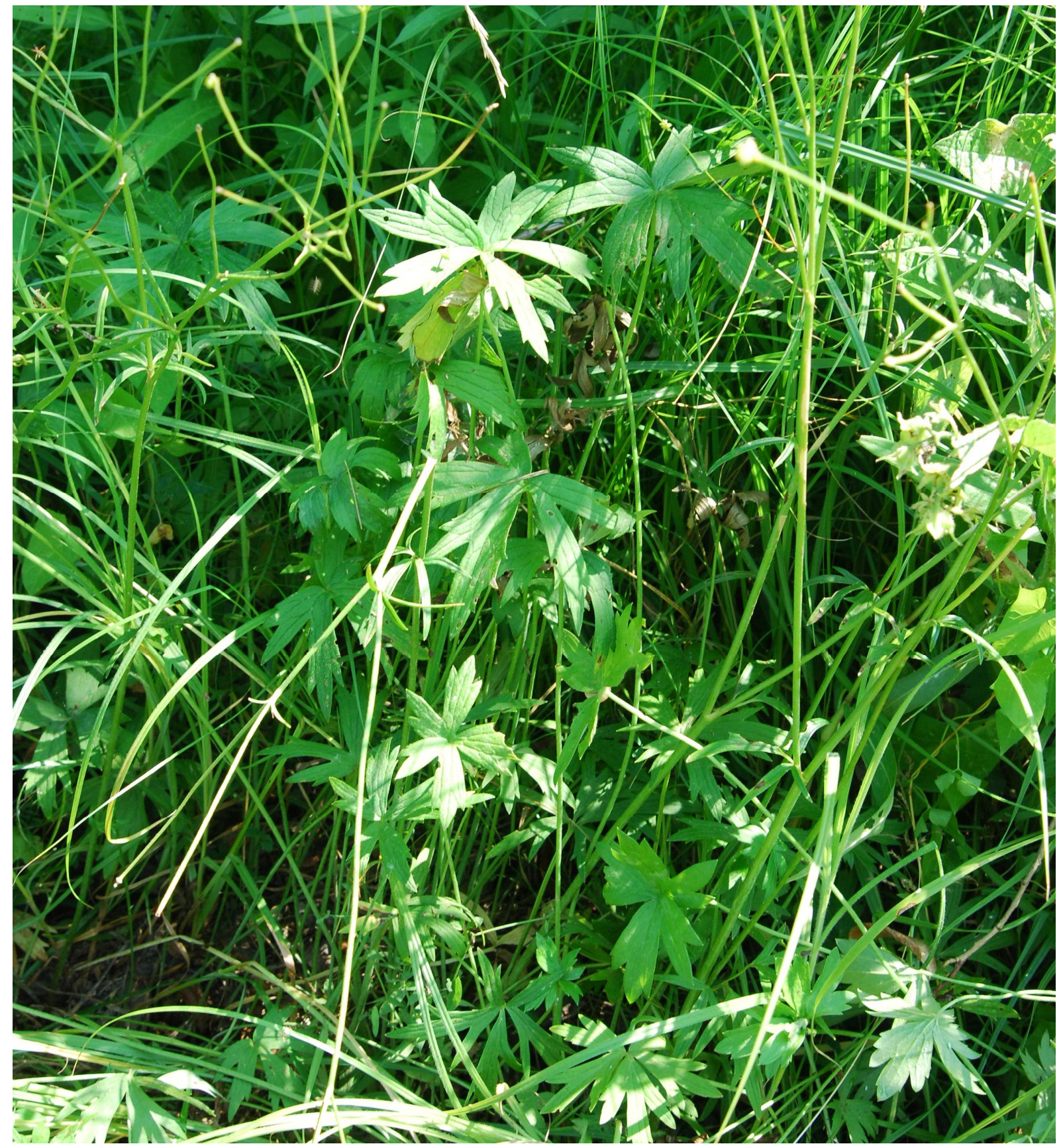

e1. ábra A „tavaszi” levelek jellegzetes formái a Tócó-völgyből (Debrecen-Józsa)

Fig. e1 Typical shapes of 'spring' leaves from the Tócó valley (Debrecen-Józsa) 


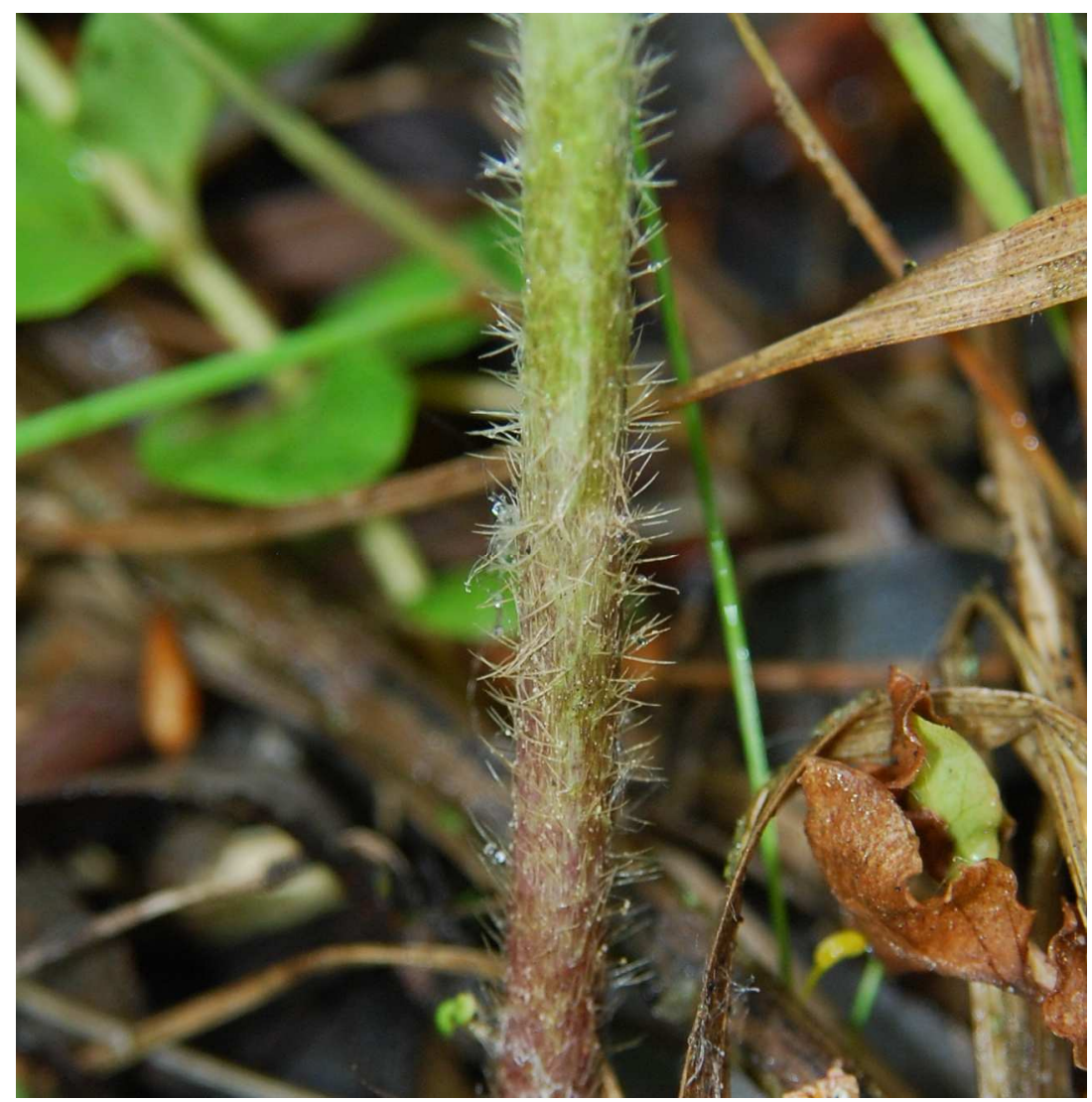

e2. ábra A szár alsó részének szőrzete Fig. e2 Hairs on the lower part of the stem

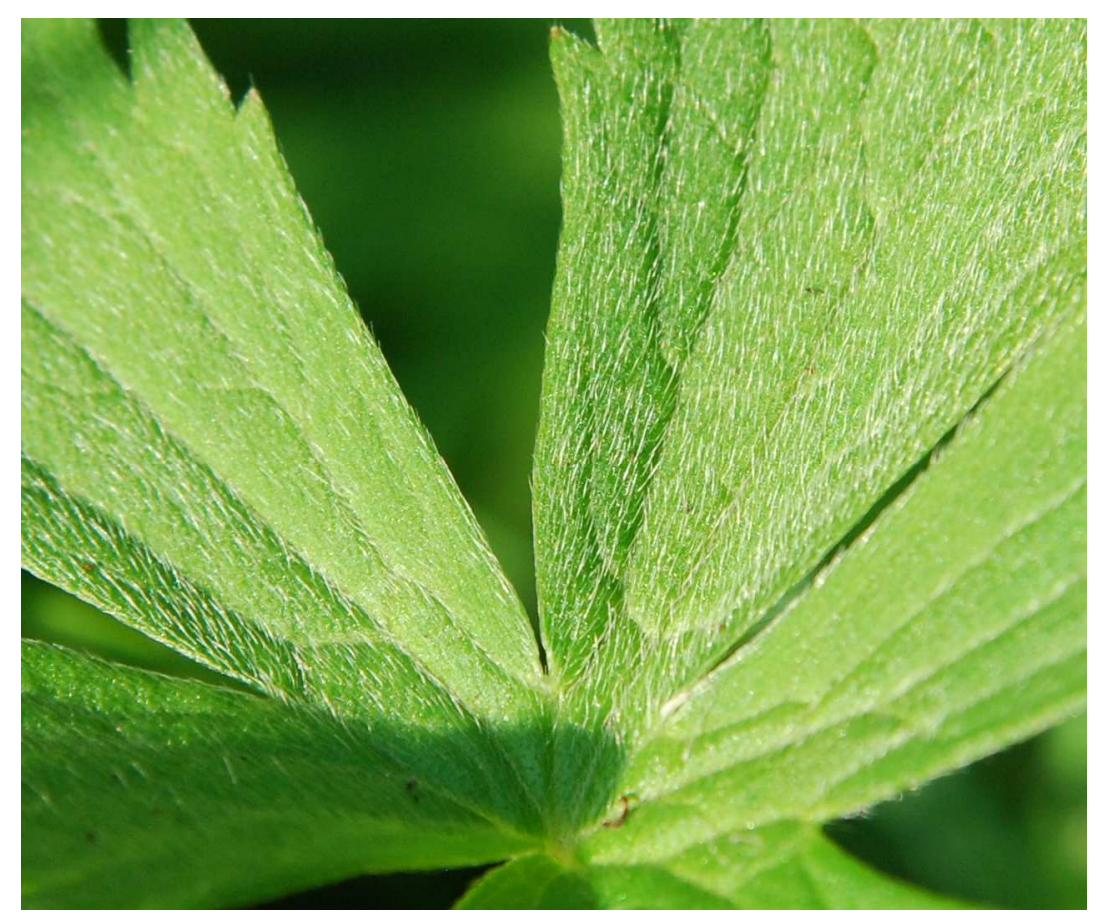

e3. ábra A „tavaszi” levelek jellegzetes szőrzete

Fig. e3 Typical hairs of 'spring' leaves 


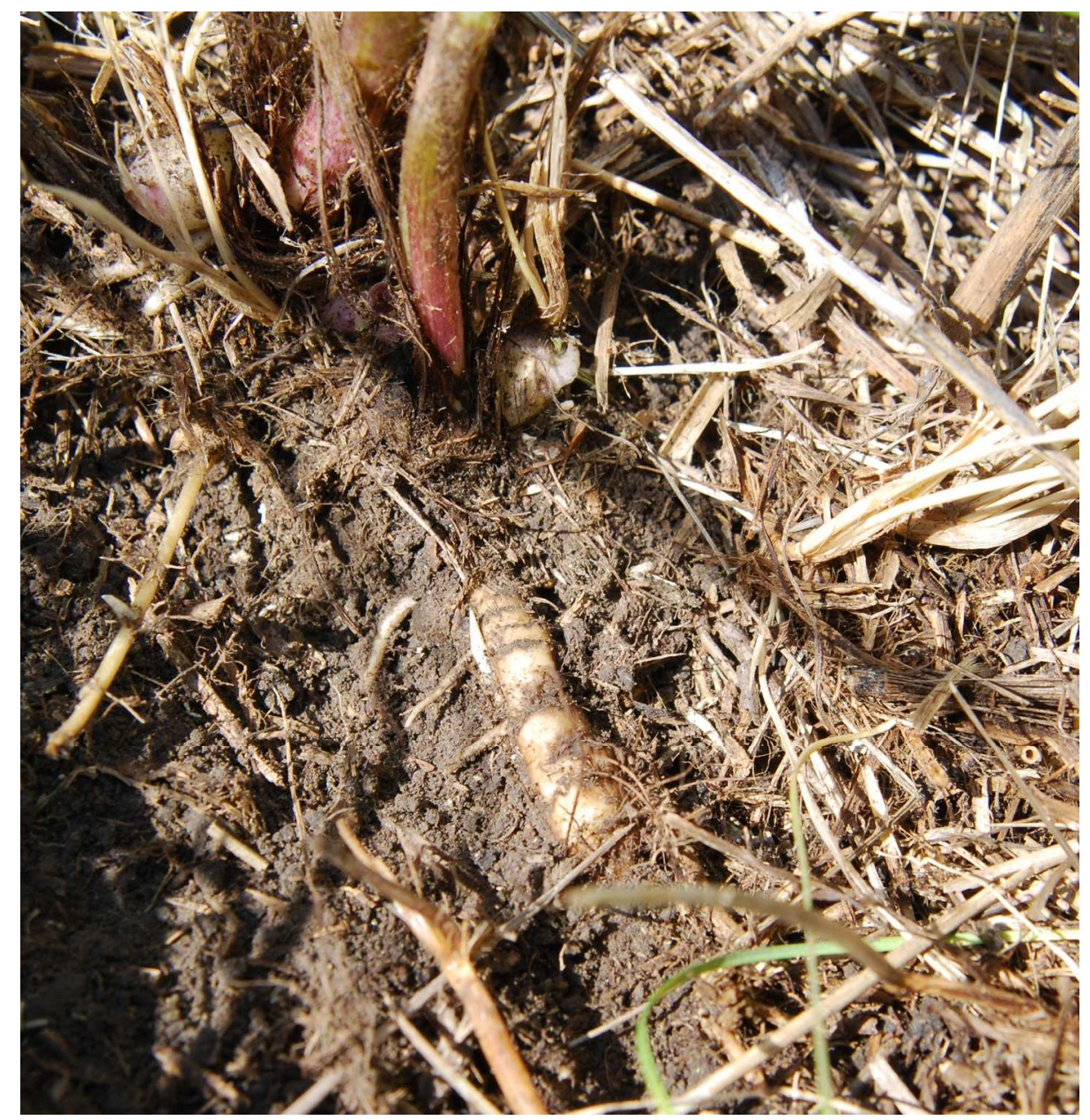

e4. ábra A gyöktörzs

Fig. e4 Rhizome

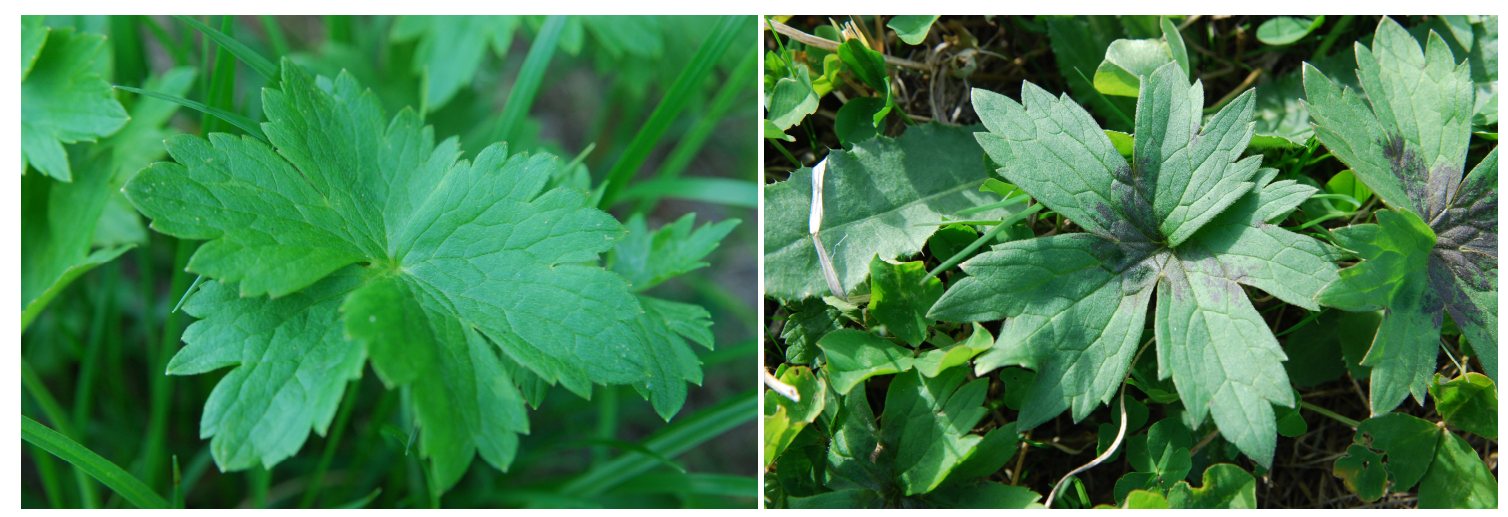

e5. ábra A kaszálás után képződött „őszi” levelek alakja Hajdúböszörményben (balra) és Nyírábrányban (jobbra) Fig. e5 The shape of leaves produced after mowing ('autumn' leaves) in Hajdúböszörmény (left) and Nyírábrány (right) 


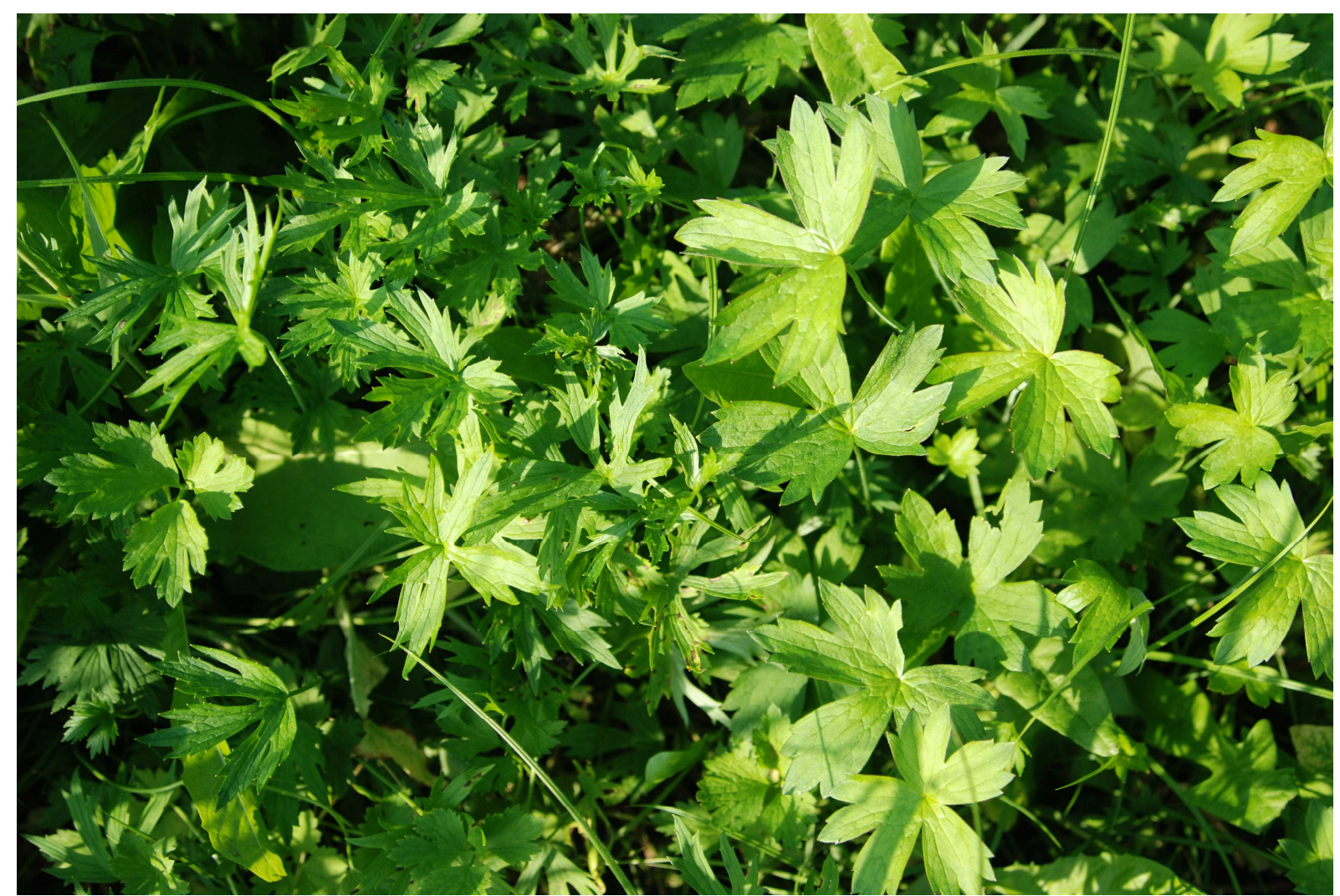

e6. ábra A Ranunculus strigulosus (jobbra), Ranunculus acris és Ranunculus repens (balra) kaszálás után kihajtott levelei (Álmosd) Fig. e6 Leaves of Ranunculus strigulosus (right), Ranunculus acris and Ranunculus repens (left) sprouted after mowing (Álmosd)

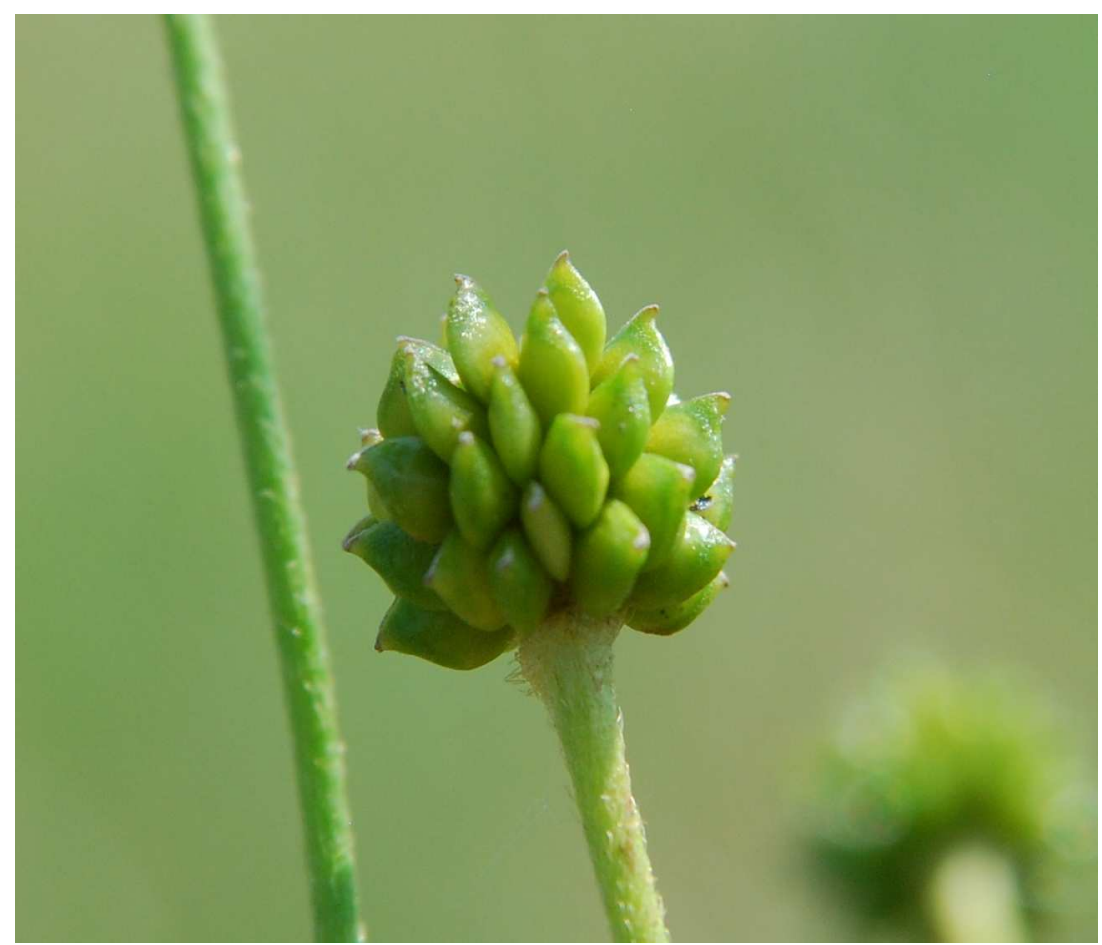

e7. ábra Tüszőcsokor Hajdúböszörményből Fig. e7 Achenes from Hajdúböszörmény 